Guanxi or weak ties? Exploring Chinese diaspora tourists' engagements in social capital building

\author{
Tingting Elle $\mathrm{Li}^{*}$ \\ Department of Marketing, Branding, and Tourism \\ Business School \\ Middlesex University London, London, United Kingdom \\ *Corresponding author \\ Email address: elle.ting@connect.polyu.hk
}




\title{
Guanxi or weak ties? Exploring Chinese diaspora tourists' engagements in social capital building
}

\begin{abstract}
Most of existing studies assume that diaspora tourism can facilitate the tourists to reconnect socially to their ancestral home. Yet, how and why diaspora tourists engage in social capital building during their home return trips is still uncertain. Whether they feel socially connected and which groups they are more likely to build connections with are unknown. This study explores the ways in which diaspora tourists foster and sustain social capital by focusing on the case of Chinese immigrants and descendants. Based on 39 in-depth interviews with Chinese home return travellers, four scenarios of how they engage in transnational social capital building are identified. The findings suggest that how a diaspora tourist constructs social capital is influenced by the individual's place and collective identity, values and perceptions he/she holds, obligations, and personal interests. Migrants in each scenario devote to building different types of social capital with ties of varied strength and depth, suggesting that the effects of diaspora tourism in facilitating the construction of social capital are different. This study advances our understanding of the social functions of diasporic return, and provides practical implications for destination managers who want to better understand the motives and social needs of home return travellers.
\end{abstract}

Keywords: social capital, diasporic return, Chinese migrants, "guanxi”, weak ties, identity

\section{Introduction}

Scattering widely in many host countries, immigrants are creating heterogeneous diaspora communities all over the world (Vertovec, 1997). The rapid development of technology and transportation allows for easier and more frequent return trips by the diasporic populations. As a result, immigrants have become one of the world's major populations "on the move", who construct networks across geographical borders in search of love, intimacy, roots, place, and identity (Tie, Holden, \& Park, 2015; Bhandari, 2016; Weaver, Kwek, \& Wang, 2017). Many recent studies have noted that return travel provides migrants with a transformative experience by connecting them physically, 
culturally and socially to their ancestral home (Alexander, Bryce, \& Murdy, 2017; Weaver et al., 2017; Huang, King, \& Suntikul, 2017). Although some of these studies have engaged with the social functions of diasporic return in one way or another (Marschall, 2017; Pelliccia, 2018; Li \& Chan, 2017), the links between diaspora tourism and social capital have been insufficiently discussed despite the growing popularity of home return trips (Gafter \& Tchetchik, 2017; Etemaddar, Duncan, \& Tucker, 2016). Indeed, new migration waves and different interactions among their members have profoundly changed the structure of diasporic communities. During different assimilation and acculturation processes, new capital has been created and maintained in association with the transformation of the migrants' personal identity, sense of place, social relations, and home return travel. Some members tend to return and reinforce their existing ties, while the others may no longer be attached to their kinship- or placebased ties but aim to establish new social connections (Zhou \& Liu, 2016).

In this study, the author uses the lens of social capital to explore migrants' social engagements when they return home. The conceptualisation of social capital provides the researchers with an innovative perspective to examine the depth, strength, and trustworthiness of the diasporas' social connections by framing such connections as long-lived assets that require continued investment and maintenance and can be accumulated, converted and used for actors' future benefits (Bourdieu,1986; Coleman, 1988; Putnam, 1995; Portes, 1998). Through a comprehensive examination of how migrants create and maintain social capital through home return travel, we seek to address the following questions: (1) In what ways can diaspora tourists sustain and foster social capital? (2) What contributes to the (re)production of their social capital? (3) Can home return travel help migrants feel socially connected? To better answer these questions, this paper looks into three dimensions (cognitive, structural and relational) of social capital built by Chinese diaspora tourists, and explores the rationale, the patterns and practices of their social capital building. By focusing on the individual's perspective, the study refers to Chinese diasporic individual's personal experience of fostering social capital, and their narratives will provide important insights to the constructive process of institutional network building in further studies (Chen, Chen, \& Huang, 2013). 
This study is situated in the context of China, where "guanxi" is widely understood as an "informal, particularistic personal connection between two individuals who are bounded by an implicit psychological contract to follow the social norms such as maintaining a long-term relationship, mutual commitment, loyalty and obligation" (Chen \& Chen, 2004, p.306). More recent studies have seen guanxi as the strong ties (Berger, Herstein, Silbiger, \& Barnes, 2018; Burt et al., 2018), and emphasised it as a critical social resource in China's economic, business and tourism development (Chen et al., 2013; Bian, 2018). The Chinese government has established multiple departments at different geographical levels (e.g. Overseas Chinese Affairs Office "Qiaoban” and “Qiaolian") to maintain high-quality guanxi with Chinese migrant associations (Zhou \& Liu, 2016). Under the banner of these institutions, an increasing number of Chinese migrants have traveled back for economic and political exchanges in the last decade (OCAO of the State Council, 2018). They have developed different types of social ties during their return: formal or informal; family or non-family; affective or instrumental; obligatory, reciprocal or utilitarian (Zhang \& Zhang, 2006; Ho, 1998), all of which could play an important part in influencing their welfare and the implementation of the government's overseas Chinese policy. Applying a qualitative research design, this study investigates the home return experiences of five generations of Chinese migrants residing in five different host countries. Based upon findings from site observations and in-depth interviews, the author argues that social capital building during home return is a complex process, in which factors such as identity, values, obligations and personal interests will combine to shape migrants' experiences of network development. This paper's discussions of diasporic individuals' experiences of home return will enrich our understanding of the mechanisms of social capital in a tourism context.

\section{Literature Review}

The literature review is structured so as to firstly review the growing significance and nuanced roles of diaspora tourism with the special attention to current publications on Chinese diaspora tourism, then discuss the main theoretical perspectives on social capital, two of the most popular strands of views and its different dimensions, and 
finally relate these discussions to the context of Chinese migrants and their "guanxi" maintenance.

\subsection{Growing relatedness of diasporas and their home return travel}

A burgeoning body of research on home return travel by migrants documents the increasing level of immigration all over the world and the popularity of visiting the home country (Weaver et al., 2017; Alexander et al., 2017; Huang, Hung, \& Chen, 2018). Amongst, a lot of these studies that have focused on diasporic return conducted by the Chinese migrants and their descendants have shed lights on the role of home return travel in transforming Chinese migrants' identity, place attachment and cultural connectedness (Tie et al., 2015; Weaver et al., 2017; Li \& McKercher, 2016a; Huang et al., 2018). This research touches on the issue of how migrants desire to maintain social connections and conceptualises such home return experience as being different from traditionally tourism which is characterised as "the loss of community" through the process of tourists' escaping from their own community to the destination community. By contrast, diaspora tourists usually have previous experiences and different extent of physical, social or spiritual connections at home (Duval, 2004). They travel back either to search for a secure sense of cultural foothold, to resolve personal identity conflicts, or simply to feel connected with their ancestors (Hollinshead, 2004; Timothy, 2008). This research opens up for further debates over the links between diaspora travel and social capital, and how a welcoming home community could provide satisfaction beyond hedonistic desires, pleasure, and a cult of consumerism (Glover \& Filep, 2015).

Thus, diaspora tourists were assumed to be more desirous to build genuine bonds with their fellow members who share a similar cultural background and identity. In some cases, they may seek to extend their old networks to reach the others who have different social identities and were not originally part of their own communities (Heimtun, 2007). Diasporic return was found to be an effective instrument to augment social capital by bringing diaspora members together into face-to-face interactions with each other (Lew \& Wong, 2004). In other cases, home return travellers may also form temporary social relations among tourists or with local residents which may be consolidated or disappear after the holiday (Pocock \& McIntosh, 2011). However, what types of social capital are formed and through which mechanisms this occurs are still the open questions in the 
current tourism and social capital literature. Considering the increasing complexity of diaspora communities and their growing mobility, it is timely to look into their social capital building in the context of diasporic return.

\subsection{Theoretical perspectives of social capital and mobility}

In this study, the author uses social capital, one of the most popular concepts exported from sociological theory into everyday language, as the lens to exploring the degree of connectedness and the quality and quantity of social relations within the Chinese migrant population (Adler \& Kwon, 2002; Portes, 1998). The theoretical foundations of the concept were established on the influential works of Bourdieu (1986), Coleman (1988), and Putnam (1995), who have defined social capital as actual or potential resources that can be used, renewed and accumulated and have an exchange value for the actors' mutual benefits. Social capital requires investment of other resources and long-standing maintenance to maintain its efficacy, and involves the exchange of both materials and feelings based on trust, reciprocity and the quality of relationships (Yang, 2001).

Two major views have been developed to comprehend the nuances of social capital (Adler \& Kwon, 2002; Woolcock \& Narayan, 2000). The bonding view emphasises the actors' internal characteristics and their actions to establish relationships within their social structure (Portes \& Sensenbrenner, 1993; Coleman, 1988). Members in the collectivity see themselves as similar in terms of social identity, and construct linkages within this collectivity to realise social cohesiveness and collective goals (Coleman, 1988). Kinship and friendship are two common forms of such social ties, and how these ties serve as sources for other types of social capital has been widely studied. In contrast, bridging capital occurs when bonded groups reach out to people or groups outside their own community who share different socio-demographic senses and identities. Through bridging, social actors aim to develop external networks and focus primarily on the heterogeneous relationships they can foster across different communities (Okazaki, 2008; McGehee, Lee, O’Bannon, \& Perdue, 2010).

However, the bonding and bridging views have been greatly challenged by the rising of mobility paradigm (Urry, 1990), whereby people travel across borders and connect with 
the absent others more conveniently, due to globalization and the rapid development of technology (Larsen, Urry, \& Axhausen, 2007). Locality may no longer be the most relevant spatial scale for the formation of social capital (Schwanen et al., 2015); instead, more people engage in building social capital beyond their place of residence. This is particularly true when we discuss the social networks developed by diasporas. Migrants can access, maintain and construct networks in varied locations and with different types of migrant communities and sub-communities (Ryan, 2011) - for instance, the migrant community in the host country and in other places of settlement, the home community in the homeland, and migrant sub-communities (based on the specific home village, clan name or interests) (Sommer \& Gamper, 2018; Lew \& Wong, 2004). As such, we cannot simply distinguish bonding from bridging capital by the external and internal views, since the unit of analysis becomes extremely complex in discussing migrants and their various sub-communities. The unit of community for analysing migrants' social networks is not static or obsolete but can be transformed through interplay among its members from different migration waves (Adler \& Kwon, 2002). Current accounts of social capital are thus insufficiently sensitive to the mobility context, and neglect the ways in which it can be mediated by the particularities of time and space (Onyx \& Leonard, 2010; Bilecen, Gamper, \& Lubbers, 2018). To solve this problem, some scholars have introduced the term "transnationalism" for understanding the process by which immigrants forge and sustain multi-stranded social relations and how such ties link together their societies of origin and settlement (Faist, 2000; Levitt, 2001). They have accordingly called for more attention to how immigrants today build social fields across geographical, cultural, and political borders (Bilecen et al., 2017; Ryan \& D’Angelo, 2018; Ryan, 2016).

Following this call, it is opportune to answer the question of how Chinese migrants maintain connections to different (sub)communities through home return travel. The author looks into three dimensions of social capital (Ostrom, 2000; Nahapiet \& Ghoshal, 1998): cognitive, structural and relational. The cognitive dimension refers to "what people think"; it indicates an individual's shared values, identities, attitudes, norms and motives, which provide the cognitive foundation for the construction of social capital (Jones, 2005). For instance, our cultural and social identity may affect our decisions on whether to maintain connections with specific cultural or social groups (Fan \& Harzing, 
2017; Adler \& Kwon, 2002). If we identify ourselves strongly with a culture that values obligations and reciprocity, we may maintain strong ties with the group/individual who has provided support for us. The structural dimension, in contrast, refers to "what people do" and relates to the composition, practices, scope and patterns of the networks that facilitate mutually beneficial action (Krishna \& Shrader, 2000; Harpham, Grant, \& Thomas, 2002). The content of social networks may influence the familiarity, intimacy, trust and obligations of our relationships.

The relational dimension indicates the quality of a social relationship in terms of its strength, trust, goodwill and helpfulness (Flora, 2004). There is an extensive body of literature researching on this dimension, and its core element of trust has been considered as the foundation of moral behaviour and the principles of reciprocity and exchange (Sorenson \& Bierman, 2009; Park, Lee, Choi, \& Yoon, 2012; Burt et al., 2018). The level of trust, together with the amount of time invested, emotional intensity, intimacy and the reciprocity in a relationship are also considered the basis to differentiate between a weak and strong tie (Granovetter, 1983). Weak ties with acquaintances are actually vital for an individual's integration into modern society (Granovetter, 1983). They are important for mobility opportunities, and are most valuable when they bridge "substantial social distance" between groups in different circles (Granovetter, 1983: 209).

\subsection{The Chinese migrant community and their guanxi development}

The Chinese diaspora is one of the largest migrant groups in the world which has reached over 60 million people spreading outside of China in more than 150 countries (Zhou, 2017). The Chinese migrant community is very complex, consisting of the older generations who migrated in different migration streams before the Open Door Policy and the new migrants who migrated after 1978. These members are from different regions of China and they show remarkable variations in levels of acculturation, identities, senses of place and transnational practices. For example, the Wuyi region is one of the largest hometowns for Chinese immigrants, where over 6 million ethnic Chinese have their ancestral roots (Jiangmen Government, 2015). During the long migration history, Chinese migrants from Wuyi have developed different identifications with places, including identity with China, identity with host country, or a mixture of 
both; they have also developed place identity with different geographical levels of home place, such as the national level (as ethnic Chinese), the provincial level (as Guangdong ren), the regional level (as Wuyi ren), and the urban level (as Jiangmen ren), etc. Thus, complexity in migrants' identity result in formation of different Chinese migrant (sub)communities. which are under formation and transformation by responding to changes of emigration contexts through the process of home-host interplay, old-new immigrants' interaction, and global geopolitical and economic restructuring (Ryan, Sales, Tilki, \& Siara, 2008; Casado-Diaz, Casado-Diaz, \& Casado-Díaz, 2014; Zhou, 2017).

The Chinese have a long history of valuing personal relationships (Chen \& Chen, 2004). The traditional meaning of guanxi in Mandarin interprets that individuals either have or do not have guanxi, and their guanxi can either be good or bad, close or distant, deep or shallow, and in tension or in harmony (Chen \& Chen, 2004). More recent studies, though, have seen guanxi as the strong ties with high level of trust which is relatively independent of the surrounding social structure (Berger et al., 2018; Burt et al., 2018). Different from the western context, the term of guanxi is rooted in the Chinese cultural norms and Confucian relationalism, where family or family-like relationships are specially emphasised as the essence of humaneness and familial collectivism. Chinese guanxi sometimes represents a commitment to the intrinsic relationship itself regardless of considerations of extrinsic costs or benefits (Hwang, 2009; King, 1991). Thus, guanxi consists of the attributes of interpersonal trust (Xinren), emotional attachment (Ganqing), and obligational favor (Renqing) that can be ascribed with our family and kinship, or achieved from voluntary associations or individuals such as colleagues, schoolmates, comrade in arms and fellow villagers (Laoxiang) (Chen et al., 2013; Bond \& Hwang, 1986).

Chinese migrants value their guanxi with migrant community members by actively joining different types of migrant associations and attending their activities to maintain social capital of such networks. For example, in the United States, the sheer number of the Chinese migrant organizations is striking. These migrant organizations are as diverse as the needs of Chinese immigrants and play a central role in their network building and guanxi maintenance (Zhou \& Liu, 2016). They not only provide 
information sharing on employment and entrepreneurship opportunities, but also serve as a platform for networking among members, alumnae, and etc. New Chinese migrants are no longer tied to pre-existing migrant organizations established by earlier Chinese immigrants or older generations of Chinese migrants. Instead, they tend to establish new organizations of their own and develop social capital within the new organizations. The profound changes in the structure of Chinese migrant communities have influenced their identity and home return travel motives. For instance, migrants who identify with their home village and adapt traditional Confucian views engage in VFR trips more often, and their repeated return visits strengthen their family relations (Nguyen \& King, 2004). Likewise, members who identify with their ancestral regions may have stronger desire to keep connections to their ancestral roots. They are more likely to join migrant association activities and return to maintain close relationships with their fellow villagers. There will be other groups who travel for developing reciprocal relationships, and expanding hierarchical, cross-community networks (Hughes \& Allen, 2010). However, it is still unknown how Chinese migrants cope with their desire, filial piety, adapted cultural values, and personal interests to build and maintain social capital during their home return travel.

\section{Research Methods}

The construction of social capital is subject to dynamic processes which can be very hard to quantify, but can be well reflected in the stories behind these processes (White, 1992). Thus, this study adopted a qualitative research design to analyse such stories and to explore the rationale underlying social capital building (Strauss \& Corbin, 1998). Semi-structured interviews and site observations (during Overseas Chinese Carnivals) were conducted by the author between October 2012 and February 2014. In order to reach a diverse sample, the author undertook fieldwork in three destinations for Chinese migrants: Los Angeles, San Francisco, and Vancouver; and two trips were made to Jiangmen Wuyi region during its Overseas Chinese Carnivals between 2012 and 2014. Snowball sampling method (Atkinson \& Flint, 2001) was used to approach participants who belong to the Chinese migrant community and have visited their home area at least once in the past. The author contacted four Chinese immigrant associations in the 
United States, Canada and Jiangmen in China ${ }^{1}$, and the leaders and members of these associations were very kind to provide support to this research project. Through their personal networks, participants were recruited and their referred family and friends who better fit the criteria of the target population were introduced to participate into the study. Kuzel's (1992) principle of data saturation was considered by discussing whether the data helped to achieve maximum variation and whether possible categories of respondents, themes and explanations emerged (Guest, Bunce, \& Johnson, 2006). The final sample includes 39 respondents from Canada, America, the UK, Japan and Brunei who have visited their ancestral home at least once in the past. The participants comprise of both genders (26 male and 13 female), and different age groups (ranging from 28 to 78 years old). 25 were born and raised in China, and 14 were born outside of China as the second to fifth generation ethnic Chinese.

Interview questions were initially designed to collect the participants' (or their ancestors') migration history, their experiences regarding home return travel, negotiation of personal identity and sense of place. All forty participants naturally brought up their social interactions with the local and migrant communities when they talked about home return experience. The author continued to ask open questions about the social connections they have built up through their home return travel, including what kinds of social connections do they build/sustain; to whom do they sustain such connections; why do they maintain such connections; and whether and how did they feel connected during return travel. Interviews were conducted in Cantonese, Mandarin, or English according to the interviewees' preferences. They were recorded and each lasts around one hour. Each interview was transcribed to texts and the names of interviewees were changed in transcriptions to ensure confidentiality. In the first stage of data analysis, inductive empirically-driven codes were created from repetitive visits of the participants' narratives, in terms of the initial patterns of social capital building. These patterns enable systematic reduction of a rich variety of data to a few relevant types for our further analysis (Sommer \& Gamper, 2018). In the second stage, the author looked into each pattern and illustrated the cognitive base, content, and quality of social ties in each initial pattern. It is during this stage that significant factors have

\footnotetext{
${ }^{1}$ Chinese Consolidate Benevolent Associations (CCBA) in San Francisco, Los Angeles, and Vancouver; Overseas Chinese Affairs Office (OCAOs) in Jiangmen Wuyi region.
} 
emerged to play roles in the formation of these patterns (Miles \& Huberman, 1994; Hsieh \& Shannon, 2005). Lastly, the author went through a process of checking codes consistency, and unnecessary codes were reduced until the final typology was achieved (Boyatzis, 1998).

One of the biggest challenges is to ensure the trustworthiness of a qualitative study by addressing the credibility, transferability, dependability and confirmability (Lincoln \& Guba, 1985). Thus, this study utilised multiple data sources, including semi-structured interviews, site observations, and secondary data such as reports from the government and Chinese migrant associations ${ }^{2}$, to achieve data triangulation. The author recruited members from multiple associations in both home and host countries to obtain the variation of data. Adequate details of the research context were also presented for other researchers who like to apply the method to similar contexts. Although the researcher's social proximity as from the similar cultural group of the participants provided a higher level of understanding for the research context, self-reflection has been done throughout the research process which aims at a better understanding of the positions of the researchers themselves and the target population to ensure academic rigor (Ganga \& Scott, 2006).

Nonetheless, the limitations of the research design should be acknowledged. First, the present study is not representative and the author did not attempt to make generalisation from the discussions of this single case. Second, the construction of guanxi become a sensitive topic in China's anti-corruption environment, and this made some of the participants less open about their specific behaviour of forming and maintaining social capital. Thus, several participants touched on the structure of their networks in China, but evaded informing the process through which they built their personal networks. Third, this study does not capture how social capital was initially built, further developed and changed overtime, but sees home return travel as a generic form of mobility and explores how this kind of mobility affects social capital building.

\footnotetext{
${ }^{2}$ Secondary documents include Document of Canadian Chinese Community and Leadership in Vancouver; Document of American Chinese Community and Leadership in New York and San Francisco; Introduction and structures of Chinese immigrant associations of Jiangmen Wuyi region (Wuyi Tongxianghui).
} 


\section{Building social capital through Chinese diaspora tourism}

From the personal narratives of the home return travellers, four social capital building scenarios were identified (as shown in Table 1). These scenarios help to justify how differently Chinese diaspora tourists create and/or maintain their social networks through diaspora tourism. They also showed why and how the Chinese diaspora members became involved in social capital building activities through different and more complex ways than previous literature has assumed. Below each of these scenarios is elaborated with case examples.

\section{Insert Table 1 About Here}

\subsection{Sustain robust bonding capital within sub-community}

Six participants reported that they mainly conducted home return trips to their ancestral home with fellow members of their own migrant associations. These trips were organised by the associations with various activities centered around their members, such as dinner parties during Spring Festivals (春茗 Chunming), visitations to ancestral houses (祭祖 Jizu), celebrations of their alma mater, etc. Through their home return travel, these individuals primarily built and/or strengthened bonding capital with the members from their own migrant sub-communities. Although some mentioned that they would invite local officials from Qiaoban, Qiaolian, and other governmental departments to their gatherings and events, they only experienced superficial exchanges with them and developed only a limited sense of trust.

For example, Li joined four migrant associations in San Francisco. These associations arrange home return trips to Jiangmen and gatherings in Wuyi area and Hong Kong every year. His frequent return trips help to strengthen his ties with association members and fellow villagers. He said:

"It [to travel back with associations] has become the major part of my life...I am a member of our associations and Wuyi ren, we make our contributions to hometown together. It is our obligations to do so... We donate money to local schools and organize dinner parties which local officials... However, we don't really have much to discuss with the local officials. Most of [the] time we just 
talk about topics of no importance [with them], have a lunch or dinner, and then leave..." (male, 60, $1^{\text {st }}$ generation, San Francisco).

This scenario is partly a result of the members' strong localised identity (e.g."Wuyi Ren", "Jiangmen Ren") as a member from Wuyi migrant community, which has been deeply embedded in their personal identity. Most expressed that they had been discriminated against as an ethnic minority during the early days of settlement in their host country. Low acculturation to the host culture restrict their lives to Chinatowns of the host countries. As such, they are keen to maintain close relationships with their village fellows from migrant associations who provide various kinds of support to their work and lives. Thus, it is noticed that most of these individuals joined more than one association which represent their ancestral area or clan names. They usually follow their association's lead and return at least once or twice per year in order to fulfil their desire to keep connected to their place of origin.

The case of Kwan has well justified the connection between his personal identity and social network building in China. He migrated from Jiangmen to San Francisco in 1960s and started to travel back with his association in 2000s. He said:

"I am more Chinese than Western. If anyone ask me, I will say I am Jiangmen ren. I cannot change my skin color, culture, and where I come from... I am Tongshi in my association, so I work and live in Chinatown. I believe here [America] is not our place, although we talk about freedom and equity. But there is no such thing as $100 \%$ freedom or equity... Because of political reason, I did not go back to China until 2000s, when my association arranged trips back and tried our best to bond our members together. So most of the time, I follow my association's schedule and activities." (Male, 68, $1^{\text {st }}$ generation, San Francisco)

This group of individuals may not have diverse home-visiting activities, but they intend to maintain social cohesion among their fellow members. They have low expectations for expanding social networks during their return; and instead, they intend to achieve a solid sense of belonging within their current sub-community by fostering a robust

\footnotetext{
${ }^{3}$ Tongshi is a job title in some Chinese migrant associations in America in charge of organizational affairs.
} 
bonding connections. In this sense, they value their own reputation as an active association member more and feel obligated to attend return activities for their associations and the whole community's benefit.

\subsection{Intensify clan-related social capital}

Ten of the respondents reported that they returned and sought to strengthen their bonding ties with their clan members. Some were first-generation migrants who returned and visited their family members residing in China, and the others were second or other distant generation migrants who returned with their family to seek ancestral roots. Their seeking for clan-related ties was observed in this pattern, manifesting how important their clan names mean to them. This is partly because of their strong Chineseness. All of these individuals identified themselves as Chinese or mostly Chinese. Although several showed that they assimilated well to the host culture, their adaptations of Chinese traditional values were evident. For instance, they valued their clan name, their family history that how and where their family started in China, the development of their clan family, etc. Hence, they stuck to a commitment to maintain intrinsic relationship with their clan, by spending time and effort to return and maintain intimacy with people who share their clan names. Thus, these individuals saw their return travel as an important family event, sometimes sacred, through which they can strengthen their bonding ties and better understand who they are. For some cases, strengthening bonding ties lead to more frequent return, and in turn increase the trustworthiness of such family relations.

Grace's case represents those migrants who value their clan name and ties, and return for maintaining such ties. She saw herself as second or third generation Chinese diaspora in America. Although she has assimilated into the American society, and she can fluently speak English, she still liked to identify herself as a "Kwok"4. She commented:

"My family was from Zhongshan. I think Zhongshan is where my roots are. I still have my cousin in Zhongshan, and we are very close. He is getting older.

\footnotetext{
${ }^{4}$ Here Kwok is a pseudonym for Grace's clan name to protect her privacy
} 
My father only has me, one girl. So I keep going back to visit my cousin because the Chinese traditional thinking is, we need to remain closer to each other when there are fewer people left in our clan. So my cousin is like a son to my father. I go back as often as I can. Each time we have family gatherings. I even brought his daughter here. She finished college and got married in San Francisco." (female, 60, $3^{\text {rd }}$ generation, Los Angeles)

\subsection{Develop flourishing networks across communities}

Fourteen participants reported that they travelled back very frequently and developed flourishing ties that include both bonding and bridging social capital. Members from this group represented the elites Chinese migrants who migrated in the last two to three decades and have better language and professional skills. They worked hard to assimilate to the mainstream of the host society, and most were confident in both cultures. They identified themselves either as mainly Chinese or Chinese American/Canadian, who were able to behave properly in both cultural contexts.

These individuals did not show strong intentions to seek for a cultural foothold, but return more independently with clear personal goals to develop business, advance economic or political exchanges, and expand social networks in China. Through their personal trips, they strengthened their existing ties and renewed some bonding ties with friends and relatives in China. Nonetheless, they appeared to have the primary need to augment bridging capital across different communities with members apart from their own community.

For example, Tony is an entrepreneur who was born and raised in Guangzhou and migrated to Canada in 1990s. He travelled to China 6-8 times per year, and devoted his time to attending overseas Chinese events and business meetings. He said:

"I don't have strong geographical sense of place, [for] we are living in a global village now. It is not like you belong to only one place... Chinese like to talk about ancestral hometown, but I don't quite do that. I behave more like a Chinese when I am in China; likewise, a Canadian in Canada. I was born in 
Guangzhou, but I travel to Jiangmen more. I usually return to the place where I have important business to do... China provides huge amount of opportunities, especially in terms of making money. [During return] I attend local events and develop some new contacts, like this year I met someone in Hangzhou and Jiangmen [from Zhongqinghui], who may provide support for our new energy project... I spend time meeting with my friends in Qiaoban, Qiaolian, and the Ministry of Commerce. We have built some good and trustworthy ties here." (male, $40,1^{\text {st }}$ generation, Toronto)

\subsection{Foster temporary and weak ties}

Nine individuals reported having developed some temporary ties with the local Chinese community through their multiple-purpose visits to China. These individuals were second- to fifth-generation ethnic Chinese, born and raised in the host countries, whose families/ancestors left ancestral hometown one or several generations ago. Their trips to China were driven by a combination of different purposes such as roots-seeking, leisure, and business. Some of them received assistance from local residents, officials, or their distant relatives during their trips. Some new ties were developed through their interactions with the local community.

For instance, Seth is a third-generation Chinese American living in Los Angeles. He visited his ancestral hometown Kaiping with his cousin in 2009 and fostered some temporary ties with his distant relatives in the village. These ties, however, felt "distant" and "superficial", lacking mutual understanding or trust due to language barriers and cultural differences:

"We met some distant relatives there, and had a chance to visit the ancestral house taken care by one of our distant relatives... It feels good to be physically reconnected to my roots, but I did not feel emotional close to my relatives... maybe because of the language barrier. I cannot speak or understand Chinese. Although we got a translator, it was hard to communicate deeply... It is good to meet some of the people I am related to. I am fascinated about how my distant 
relatives think of me when I was there. They might think of us as outsiders..." (male, 42, $3^{\text {rd }}$ generation, Los Angeles)

This feeling of being "outsiders" may be resulted from their deep roots in host countries and evidently cultural distance between them and their ancestral home. Instead of feeling belonged to the Chinese community, most of these people see themselves as Westerners. A few had a mixed identity with variable levels of Chinese attachment depending on how much cultural exposure they had during their formative years. Thus, they expressed that their social networks were mostly established and maintained in their current home and it was difficult to develop strong ties during their short stay in China. Nonetheless, a few tourists strengthened their new ties through repeated visits, while the others saw their ties grow weaker with time.

\section{Discussions and conclusion}

This research has explored the links between diaspora tourism and social capital building through a case study of Chinese home return travellers. The four scenarios for the construction of their transnational social networks address the questions of how diaspora tourists foster and maintain social capital, what contributes to the (re)production of their social capital, and can home return travel help them feel connected. The findings suggest that how migrants develop and maintain social capital in their homeland is associated with different patterns of return travel, in terms of travel frequency, length of stay, and activities. Moreover, the types, strength and depth of the social capital they build are very different in these scenarios, as I will now discuss in detail.

\subsection{The significant roles of place and collective identity}

In the four scenarios, the paper has highlighted the significant role of identity in the social capital building of Chinese diaspora tourists. The role of identity in the (re) production of social networks has rarely been discussed in previous studies, except for a few that touch on the links between social identity, values and personal interests when tourists receive the hospitality of friends and kin who live elsewhere, as part of social 
obligations (Larsen et al., 2007; Mura \& Tavakoli, 2014; Li \& McKercher, 2016b). It is found that the group of tourists who identified strongly with their ancestral region or migrant association(s) (Scenario 1) return more frequently to their ancestral hometown, and prefer to centre their social capital building in their hometown and/or within migrant associations. Such cases reveal the strong geographical character of migrants' social capital, as where migrants return to and how they maintain their social networks are deeply affected by their identification with place.

Diasporic individuals' collective identity as Chinese or as a member of the Chinese migrant community is another critical factor in their decision to return and how they maintain social networks. Migrants with a strong sense of Chineseness (Scenario 1 and 2) returned more frequently than other groups, and their social networks building was based on Chinese traditional values, especially the Confucian emphasis on kinship and family (Ho, 1998) and the importance of maintaining harmony and intimacy among clan members (Chen et al., 2013). Thus, through VFR travel (Ashtar, Shani, \& Uriely, 2017; Griffin, 2014), diasporic individuals foster intensive bonding capital among family and association members, developing obligations and commitments to sustain the sense of kinship and friendship (Chen et al., 2013; Hwang, 2009). Their home return travel leads naturally to intensification of these strong ties, and in turn such guanxi involves a higher level of interpersonal trust, care and concern for the social and psychological welfare of the self and family.

\subsection{Connecting via home return travel?}

The findings also open up further debate over the social role of diaspora tourism, by answering the question of whether diaspora tourists feel socially connected via return. The current literature generally discusses the role of diaspora tourism in facilitating migrant's reunion with their home community by strengthening their physical, emotional and social connections (Huang et al., 2018; Weaver et al., 2017). This research extends this discussion to whether tourists can truly feel socially connected during their home return travel. The evidence shows that some migrants develop a higher level of trust and loyalty in connection with their fellow migrants, families and local community when they return frequently and maintain ties in a relatively close social structure (Scenario 1 and 2). This finding is in line with previous research that 
has shown trust increases within a relationship as network closure increases (Burt et al., 2018). In the case of Chinese migrants, the migrant associations provide a strong cultural foothold, shared place and collective identity, which increase mutual trust when they maintain their networks.

However, the increasing number of Chinese migrant associations and the complex structure of the current Chinese migrant community challenge migrants' social relationships building when they return. Such complexity results in different motives for return and different extents of emotional interaction and trust achieved by diaspora tourists (Zhou, 2017; Zhou \& Liu, 2016; Li \& Chan, 2018). The younger generation has become the backbone of the Chinese migrant community and actively engages in building extensive social networks through their home return travel (Scenario 3), while the older generations who migrated from the 1940s to the $1970 \mathrm{~s}$ are facing transformation of migrant communities (Zhou \& Liu, 2016). Their reputations and sense of trust in their migrant associations are greatly affected by their social status and the transformation, which further affects their social capital maintenance when they return.

\subsection{Connecting through weak ties?}

The study also identified two types of tourists who travel back and build weak ties within or across communities. These tourists, however, use weak ties for different purposes. Some are considered the elite in the Chinese migrant community; they conduct frequent return visits driven by personal interests, visions and aspirations, and expand their social networks to different communities (Scenario 3). Through this expansion, they foster weak ties across different Chinese communities and strengthen some ties so that they can be used in the future. These weak ties are seen as valuable resources (Granovetter, 1983) for Chinese elite migrants who seek mobility and business opportunities and make special efforts to maintain useful ties to other communities for potential cooperation. Their cases represent the ego-pragmatic perspective of guanxi, which involves the exchange of favours for the focal actors' benefit (Bian, 1997; Xiao \& Tsui, 2007).

The other group is characterized as roots tourists, who return to their ancestral hometown in search of their roots and forge temporary ties with local villagers and 
officials (Scenario 4). However, as Granovetter (1983) emphasised, not all weak ties are equally valuable. The weak ties fostered by some roots-seeking tourists may lack trust. Some participants stated that they felt like "outsiders" in their ancestral home, and failed to connect deeply with distant relatives and villagers. Due to the long migration histories and generational distance they experienced, the connections they build through returning home may be shallow and temporary. These ties may grow or disappear with time, as social capital is vulnerable and requires investment of other resources to maintain its effectiveness (Adler \& Kwon, 2002).

\subsection{Implications, conclusion remarks and future research avenues}

This study has a number of implications. First, the findings unveil the close links between diaspora tourism and social capital through the paralleled view from previous studies on the nurturing role of tourism in enhancing social relationships (Mura \& Tavakoli, 2014; Zahra \& McGehee, 2013). Empirical evidence shows how diaspora tourism offers diverse experience of social capital building among migrants with different identities, values and purposes. To some migrants, home return travel and social capital building are relatively private so that they prefer to keep to their own (sub)community or family; while others are keen to extend their social networks to other communities and develop ties to resources that they can use for future benefits. The strength of their social capital is different as well. Some can only foster temporary, weak ties with the local community, while others intensify their ties to develop a strong and reliable network.

The discussions also raise further concerns over the differentiation between bonding and bridging social capital when discussing the links between migrants' return mobility and social capital they have maintained. Recent studies of transnational social networks have mainly focused on the differences between bonding and bridging capital augmented by migrants or migrant entrepreneurs, and argued that migrants can use their advantages of language skills, knowledge of different markets, and ability to flexibly operate between different cultural systems to obtain trust, reciprocity and cooperation (Casado-Díaz et al., 2014; Soulard, Knollenberg, Boley, perdue, \& McGehee, 2018; Zhao, Ritchie, \& Echtner, 2011; Ngoason \& Kimbu, 2016; Sommer \& Gamper, 2018). However, the findings suggest that we cannot simply differentiate migrants' bonding 
ties from their bridging ties, due to the complex structure of migrant communities, constant interplay among migrants, and blurred boundaries between various subcommunities (Zhou \& Liu, 2016). We need a more dynamic view to understanding diaspora community and their social capital building (Ryan \& D'Angelo, 2018). The different scenarios identified here provide a more comprehensive understanding of social capital building by the migrant community.

Further, the findings contribute to exploring the mechanism underlying migrants' social capital building scenarios. By noting that migrants' personal identity, values, and personal interests play significant roles in determining their return motives and engagements in social capital building activities, the study has uncovered the cognitive basis of migrants' social capital maintenance. Individuals who maintain a strong regional identity and have lower levels of acculturation are more likely to confine their social network building to their ancestral region and the sub-communities to which they belong (Scenario 1 and 2). Some cases (Scenario 2) reflect the strong influence of Confucian views of developing family-like guanxi, whereas in other cases (Scenario 4), generational distance and cultural differences make it difficult to develop deep interpersonal relationships. The latter group's bridging capital is thus built in a superficial manner, and some of these ties may not withstand the passage of time if the tourists no longer return or invest other resources in the relationship.

This study also has management implications by providing a comprehensive understanding of overseas Chinese tourists in terms of building and maintaining social networks to different geographical levels of (national, regional and local) OCAOs and other governmental departments in China. Policy formulation which aims to facilitate more satisfactory experience of return and attract more tourists to return and fulfil their quests and ambitions will be facilitated. Future research could use mixed-method approach that combines qualitative inquiry and quantitative studies to provide deeper insights into the mechanism, contents and structures of social network built by migrants and tourists. The findings also reveal a need for future research on the locally and culturally specific aspects of social capital building in modern China and how such aspects can be linked to the development of its tourism industry. 
References:

Adler, P. S., \& Kwon, S.-W. (2002). Social capital: Prospects for a new concept. Academy of Management Review, 27(1), 17-40.

Alexander, M., Bryce, D., \& Murdy, S. (2017). Delivering the past: providing personalized Ancestral Tourism experiences. Journal of Travel Research, 56(4), 543-555.

Ashtar, L., Shani, A., \& Uriely, N. (2017). Blending 'home'and 'away': young Israeli migrants as VFR travelers. Tourism Geographies, 19(4), 658-672.

Atkinson, R., \& Flint, J. (2001). Accessing hidden and hard-to-reach populations: Snowball research strategies. Social Research Update, 33(1), 1-4.

Berger, R., Herstein, R., Silbiger, A., \& Barnes, B. R. (2018). Is guanxi universal in China? Some evidence of a paradoxical shift. Journal of Business Research, 86, 344-355.

Bhandari, K. (2016). Imagining the Scottish nation: Tourism and homeland nationalism in Scotland. Current Issues in Tourism, 19(9), 913-929.

Bian, Y. (1997). Bringing strong ties back in: Indirect ties, network bridges, and job searches in China. American Sociological Review, 62(3), 366-385.

Bian, Y. (2018). The prevalence and the increasing significance of guanxi. The China Quarterly,235 597-621.

Bilecen, B., Gamper, M., \& Lubbers, M. J. (2018). The missing link: Social network analysis in migration and transnationalism. Social Networks, 53, 1-3. 
Bond, M. H., \& Hwang, K.-k. (1986). The social psychology of Chinese people. In M. H. Bond (Ed.), The psychology of the Chinese people (pp. 213-266). New York, NY, US: Oxford University Press.

Bourdieu, P. (1986). The forms of capital. In J. E. Richardson (Ed.), Handbook of theory of research of education (Vol. 1, pp. 241-258). New York: Greenwood Press.

Boyatzis, R. E. (1998). Transforming Qualitative Information: Thematic Analysis and Code Development. Thousand Oaks, California: Sage Publications.

Burt, R. S., Bian, Y., \& Opper, S. (2018). More or less guanxi: Trust is $60 \%$ network context, $10 \%$ individual difference. Social Networks, 54, 12-25.

Casado-Díaz, M. A., Casado-Díaz, A. B., \& Casado-Díaz, J. M. (2014). Linking tourism, retirement migration and social capital. Tourism Geographies, 16(1), 124-140.

Chen, C. C., Chen, X. P., \& Huang, S. (2013). Chinese Guanxi: An integrative review and new directions for future research. . Management and Organization Review, 9(1), 167-207.

Chen, X.-P., \& Chen, C. C. (2004). On the intricacies of the Chinese guanxi: A process model of guanxi development. Asia Pacific Journal of Management, 21(3), 305-324.

Coleman, J. (1988). Social capital in the creation of human capital. American Journal of Sociology, 94, 95-120.

Duval, D. T. (2004). Linking return visits and return migration among Commonwealth Eastern Caribbean migrants in Toronto. Global Networks, 4(1), 51-67.

Etemaddar, M., Duncan, T., \& Tucker, H. (2016). Experiencing 'moments of home'through diaspora tourism and travel. Tourism Geographies, 18(5), 503-519.

Fan, S. X., \& Harzing, A.-W. (2017). Host country employees' ethnic identity confirmation: Evidence from interactions with ethnically similar expatriates. Journal of World Business, 52(5), 640-652.

Faist, T. (2000). Transnationalization in international migration: Implications for the study of citizenship and culture. Ethnic and Racial Studies, 23(2), 189-222.

Flora, C. B. (2004). Community dynamics and social capital. In D. Rickerl \& C. Francis (Eds.), Agroecosystems analysis (pp. 93-107): Madison, WI American Society of Agronomy.

Gafter, L. M., \& Tchetchik, A. (2017). The role of social ties and communication technologies in visiting friends tourism-A GMM simultaneous equations approach. Tourism Management, 61, 343-353.

Ganga, D., \& Scott, S. (2006). Cultural" insiders" and the issue of positionality in qualitative migration research: Moving" across" and moving" along" researcher-participant divides. Paper presented at the Forum Qualitative Sozialforschung/Forum: Qualitative Social Research.

Glover, T. D., \& Filep, S. (2015). On kindness of strangers in tourism. Annals of Tourism Research, 50, 159-162. 
Granovetter, M. (1983). The strength of weak ties: A network theory revisited. Sociological Theory, 201-233.

Griffin, T. (2014). A paradigmatic discussion for the study of immigrant hosts. Current Issues in Tourism, 17(6), 487-498.

Guest, G., Bunce, A., \& Johnson, L. (2006). How many interviews are enough? An experiment with data saturation and variability. Field methods, 18(1), 59-82.

Harpham, T., Grant, E., \& Thomas, E. (2002). Measuring social capital within health surveys: key issues. Health Policy and Planning, 17(1), 106-111.

Heimtun, B. (2007). Depathologizing the tourist syndrome: Tourism as social capital production. Tourist Studies, 7(3), 271-293.

Ho, D. Y. (1998). Interpersonal relationships and relationship dominance: An analysis based on methodological relationism. Asian Journal of Social Psychology, 1(1), 1-16.

Hollinshead, K. (2004). Tourism and third space populations. In T. Coles \& D. J. Timothy (Eds.), Tourism, Diasporas and Space (pp. 33-49). London: Routledge.

Hsieh, H.-F., \& Shannon, S. E. (2005). Three approaches to qualitative content analysis. Qualitative Health Research, 15(9), 1277-1288.

Huang, W. J., King, B., \& Suntikul, W. (2017). VFR Tourism and the Tourist Gaze: Overseas Migrant Perceptions of Home. International Journal of Tourism Research, 19(4), 421434.

Huang, W. J., Hung, K., \& Chen, C. C. (2018). Attachment to the home country or hometown? Examining diaspora tourism across migrant generations. Tourism Management, 68, 5265.

Hughes, H., \& Allen, D. (2010). Holidays of the Irish diaspora: The pull of the 'homeland'? Current Issues in Tourism, 13(1), 1-19.

Hwang, K.-k. (2009). Confucian relationalism: Cultural reflection and theoretical construction. Beijing: Beijing University Press.

Jiangmen Government. (2015). The Government Report of Tourism Arrivals. Jiangmen.

Jones, S. (2005). Community-based ecotourism: The significance of social capital. Annals of Tourism Research, 32(2), 303-324.

King, A. Y. (1991). Kuan-hsi and network building: A sociological interpretation. Daedalus, $120(2), 63-84$.

Krishna, A., \& Shrader, E. (2000). Cross-cultural measures of social capital: A tool and results from India and Panama. Social capital initiative working paper (Vol. 21). Washington, D. C. : World Bank.

Kuzel, A. J. (1992). Sampling in qualitative inquiry. In C. B. F. \& M. W. L. (Eds.), Research methods for primary care: Doing qualitative research (Vol. 3, pp. 31-44). Thousand Okas, CA: Sage Publications. 
Larsen, J., Urry, J., \& Axhausen, K. W. (2007). Networks and tourism: Mobile social life. Annals of Tourism Research, 34(1), 244-262.

Lew, A., \& Wong, A. (2004). Sojourners, guanxi and clan associations: social capital and overseas Chinese tourism in China. In T. Coles \& D. J. Timothy (Eds.), Tourism, Diasporas and Space. New York: Routledge.

Levitt, P. (2001). Transnational migration: taking stock and future directions. Global Networks, l(3), 195-216.

Lincoln, Y. S., \& Guba, E. G. (1985). Naturalistic Inquiry. London: Sage.

Li, T. E., \& Chan, T. (2017). Diaspora tourism and well-being: A eudaimonic view. Annals of Tourism Research, 63, 205-206.

Li, T. E., \& Chan, E. T. H. (2018). Connotations of ancestral home: An exploration of place attachment by multiple generations of Chinese diaspora. Population, Space and Place, 24(8), e2147.

Li, T. E., \& McKercher, B. (2016a). Developing a typology of diaspora tourists: Return travel by Chinese immigrants in North America. Tourism Management, 56, 106-113.

Li, T. E., \& McKercher, B. (2016b). Effects of place attachment on home return travel: A spatial perspective. Tourism Geographies, 18(4), 359-376.

Marschall, S. (Ed.). (2017). Tourism and memories of home: migrants, displaced people, exiles and diasporic communities. Bristol, UK: Channel View Publications.

McGehee, N. G., Lee, S., O'Bannon, T. L., \& Perdue, R. R. (2010). Tourism-related social capital and its relationship with other forms of capital: An exploratory study. Journal of Travel Research, 49(4), 486-500.

Miles, M. B., \& Huberman, A. M. (1994). Qualitative data analysis: An expanded sourcebook. London: Sage Publications.

Mura, P., \& Tavakoli, R. (2014). Tourism and social capital in Malaysia. Current Issues in Tourism, 17(1), 28-45.

Nahapiet, J., \& Ghoshal, S. (1998). Social capital, intellectual capital, and the organizational advantage. Academy of Management Review, 23(2), 242-266.

Ngoasong, M. Z., \& Kimbu, A. N. (2016). Informal microfinance institutions and developmentled tourism entrepreneurship. Tourism Management, 52, 430-439.

Nguyen, T.-H., \& King, B. (2004). The culture of tourism in the diaspora. In T. Coles \& D. J. Timothy (Eds.), Tourism, diasporas, and space (pp. 172). London: Routledge.

OCAO of the State Council. (2018). Overseas Chinese Visited Ancestral Home for Rootseeking: To Feel China. Retrieved 1 July, 2018, from http://www.gqb.gov.cn/news/2018/0720/45163.shtml

Okazaki, E. (2008). A community-based tourism model: Its conception and use. Journal of Sustainable Tourism, 16(5), 511-529. 
Onyx, J., \& Leonard, R. (2010). The conversion of social capital into community development: an intervention in Australia's outback. International Journal of Urban and Regional Research, 34(2), 381-397.

Ostrom, E. (2000). Social capital: a fad or a fundamental concept (Vol. 172). Washington, D. C.: The International Bacnk for Reconstruction and Development.

Park, D. B., Lee, K. W., Choi, H. S., \& Yoon, Y. (2012). Factors influencing social capital in rural tourism communities in South Korea. Tourism Management, 33(6), 1511-1520.

Pelliccia, A. (2018). In the family home: roots tourism among Greek second generation in Italy. Current Issues in Tourism, 21(18), 2108-2123.

Pocock, N. J., \& McIntosh, A. J. (2011). The return from travel: A new beginning? Current Issues in Tourism, 14(7), 631-649.

Portes, A. (1998). Social capital: Its origins and applications in modern sociology. Annual Review of Sociology, 24(1), 1-24.

Portes, A., \& Sensenbrenner, J. (1993). Embeddedness and immigration: Notes on the social determinants of economic action. American Journal of Sociology, 98(6), 1320-1350.

Putnam, R. D. (1995). Bowling alone: America's declining social capital. Journal of Democracy, 6(1), 65-78.

Ryan, L., Sales, R., Tilki, M., \& Siara, B. (2008). Social networks, social support and social capital: The experiences of recent Polish migrants in London. Sociology, 42(4), 672-690.

Ryan, L., \& D'Angelo, A. (2018). Changing times: Migrants' social network analysis and the challenges of longitudinal research. Social Networks, 53, 148-158.

Ryan, L. (2011). Migrants' social networks and weak ties: accessing resources and constructing relationships post-migration. The Sociological Review, 59(4), 707-724.

Ryan, L. (2016). Looking for weak ties: using a mixed methods approach to capture elusive connections. The Sociological Review, 64(4), 951-969.

Schwanen, T., Lucas, K., Akyelken, N., Solsona, D. C., Carrasco, J.-A., \& Neutens, T. (2015). Rethinking the links between social exclusion and transport disadvantage through the lens of social capital. Transportation Research Part A: Policy and Practice, 74, 123135.

Sommer, E., \& Gamper, M. (2018). Transnational entrepreneurial activities: A qualitative network study of self-employed migrants from the former Soviet Union in Germany. Social Networks, 53, 136-147.

Sorenson, R. L., \& Bierman, L. (2009). Family capital, family business, and free enterprise. Family Business Review, 22(3), 193-195.

Soulard, J., Knollenberg, W., Boley, B. B., Perdue, R. R., \& McGehee, N. G. (2018). Social capital and destination strategic planning. Tourism Management, 69, 189-200.

Strauss, A., \& Corbin, J. (1998). Basics of qualitative research techniques: Sage publications. 
Tie, C., Holden, A., \& Park, H. (2015). A 'reality of return': The case of the SarawakianChinese visiting China. Tourism Management, 47, 206-212.

Timothy, D. J. (2008). Genealogical Mobility: Tourism and the search for a personal past. In D.

J. Timothy \& J. K. Guelke (Eds.), Geography and genealogy: Locating personal pasts (pp. 115). Hampshire: Ashgate Publishing Limited.

Urry, J. (1990). The consumption of tourism. Sociology, 24(1), 23-35.

Vertovec, S. (1997). Three meanings of" diaspora," exemplified among South Asian religions. Diaspora: A Journal of Transnational Studies, 6(3), 277-299.

Weaver, D. B., Kwek, A., \& Wang, Y. (2017). Cultural connectedness and visitor segmentation in diaspora Chinese tourism. Tourism Management, 63, 302-314.

White, H. C. (1992). Identity and control: A structural theory of social action: Princeton University Press Princeton, NJ.

Woolcock, M., \& Narayan, D. (2000). Social capital: Implications for development theory, research, and policy. The World Bank Research Observer, 15(2), 225-249.

Xiao, Z., \& Tsui, A. S. (2007). When brokers may not work: The cultural contingency of social capital in Chinese high-tech firms. Administrative Science Quarterly, 52(1), 1-31.

Yang, C. (2001). A reconceptualization of the Chinese guanxi and renqing. In C. F. Yang (Ed.), The Interpersonal Relationship, Affection, and Trust of the Chinese: Froman Interactional Perspective (pp. 337-370). Taipei: Yuan Liou Publishing and Institutions.

Zahra, A., \& McGehee, N. G. (2013). Volunteer tourism: A host community capital perspective. Annals of Tourism Research, 42, 22-45.

Zhang, Y., \& Zhang, Z. (2006). Guanxi and organizational dynamics in China: A link between individual and organizational levels. Journal of Business Ethics, 67 (4): 375-392.

Zhao, W., Ritchie, J. B., \& Echtner, C. M. (2011). Social capital and tourism entrepreneurship. Annals of Tourism Research, 38(4), 1570-1593.

Zhou, M. (2017). Contemporary Chinese Diasporas: Springer.

Zhou, M., \& Liu, H. (2016). Homeland engagement and host-society integration: A comparative study of new Chinese immigrants in the United States and Singapore. International Journal of Comparative Sociology, 57(1-2), 30-52. 
Table 1. Social capital building via Chinese diaspora tourism

\begin{tabular}{|c|c|c|c|}
\hline $\begin{array}{l}\text { Scenarios of social } \\
\text { capital building }\end{array}$ & Cognitive dimension & Structural dimension & Relational dimension \\
\hline $\begin{array}{l}\text { Sustain robust } \\
\text { bonding capital } \\
\text { within sub- } \\
\text { community }\end{array}$ & $\begin{array}{l}\text {-Identities: Shared } \\
\text { strong regional identity } \\
\text { (e.g. Wuyi ren) and } \\
\text { migrant association } \\
\text { leader/membership } \\
\text { identity } \\
\text {-Values: Importance of } \\
\text { "face" and reputation to } \\
\text { keep the belonged } \\
\text { migrant association's } \\
\text { cohesion } \\
\text {-Personal interests: to } \\
\text { perform obligations as } \\
\text { the migrant association } \\
\text { member }\end{array}$ & $\begin{array}{l}\text {-High bonding capital } \\
\text { within migrant } \\
\text { association members, } \\
\text {-Some bonding capital } \\
\text { with family members } \\
\text { and friends } \\
\text {-Low bridging capital } \\
\text { with local communities }\end{array}$ & $\begin{array}{l}\text { Trust-increasing ties within } \\
\text { belonged migrant } \\
\text { associations } \\
\text { Limited exchanges with } \\
\text { local communities }\end{array}$ \\
\hline $\begin{array}{l}\text { Intensify clan-related } \\
\text { social capital }\end{array}$ & $\begin{array}{l}\text {-Identities: Chinese \& } \\
\text { strong ancestral } \\
\text { hometown identity (e.g. } \\
\text { Jiangmen ren); mixed } \\
\text { home and host identity } \\
\text {-Values: Shared } \\
\text { Confucian value of } \\
\text { harmony with family } \\
\text { - Personal interests: } \\
\text { Seeking family } \\
\text { commonality, reunion } \\
\text { and connections }\end{array}$ & $\begin{array}{l}\text {-Strong family bonding } \\
\text { capital within family } \\
\text { members in home and } \\
\text { host places } \\
\text {-Some bridging capital } \\
\text { with local officials }\end{array}$ & $\begin{array}{l}\text { Strong and trust-increasing } \\
\text { ties }\end{array}$ \\
\hline $\begin{array}{l}\text { Develop flourishing } \\
\text { ties across } \\
\text { communities } \\
\end{array}$ & $\begin{array}{l}\text {-Identities: Chinese or } \\
\text { mixed identity } \\
\text {-Values: Flexibly adjust }\end{array}$ & $\begin{array}{l}\text { - Strengthen existing } \\
\text { social ties with } \\
\text { community members, }\end{array}$ & $\begin{array}{l}\text { Strong ties with mutual } \\
\text { trust and potential for } \\
\text { cooperation }\end{array}$ \\
\hline
\end{tabular}




\begin{tabular}{|c|c|c|c|}
\hline & $\begin{array}{l}\text { values and behaviours } \\
\text { according to the place } \\
\text { they visit } \\
\text {-Personal interests: } \\
\text { Aspirations for personal } \\
\text { and business } \\
\text { development }\end{array}$ & $\begin{array}{l}\text { friends and relatives } \\
\text {-Extend ties across } \\
\text { communities to local } \\
\text { officials, entrepreneurs, } \\
\text { and local residents }\end{array}$ & $\begin{array}{l}\text { Weak ties with members of } \\
\text { different communities }\end{array}$ \\
\hline $\begin{array}{l}\text { Foster temporary } \\
\text { and weak ties }\end{array}$ & $\begin{array}{l}\text { - Identities: Identify } \\
\text { with the host place } \\
\text { - Values: Mixed values } \\
\text { of home and host; value } \\
\text { the importance of } \\
\text { understanding one's } \\
\text { personal past } \\
\text { - Personal interests: } \\
\text { Shared aspirations of } \\
\text { seeking and confirming } \\
\text { personal roots }\end{array}$ & $\begin{array}{l}\text {-Weak and temporary } \\
\text { bridging capital with } \\
\text { local community } \\
\text { - Weak familial bonding } \\
\text { capital in home area }\end{array}$ & $\begin{array}{l}\text { Feel like "outsider" } \\
\text { Limited exchanges or } \\
\text { reciprocity }\end{array}$ \\
\hline
\end{tabular}

Appendix 1. Profile of participants

\begin{tabular}{lllllll}
\hline $\begin{array}{l}\text { Social capital } \\
\text { building patterns }\end{array}$ & Pseudonym & Age & Gender & Generation & $\begin{array}{l}\text { Current place } \\
\text { of residence }\end{array}$ & Employment \\
\hline $\begin{array}{l}\text { Robust bonding } \\
\text { capital within sub- } \\
\text { communities }\end{array}$ & Li & 60 & Male & 1 & San Francisco & $\begin{array}{l}\text { Headmaster of } \\
\text { primary school }\end{array}$ \\
& Chan & 55 & Male & 1 & Los Angeles & $\begin{array}{l}\text { Self-employed } \\
\end{array}$ \\
& Jordan & 43 & Male & 1 & Vancouver & Entrepreneur \\
& Kwan & 68 & Male & 1 & San Francisco & Retired \\
& Gwan & 65 & Male & 1 & Brunei & Retired \\
\hline No. of participants & 6 & 56 & Male & 1 & Los Angeles & Entrepreneur \\
\hline Intensive clan- & Peter & 28 & Male & $1(1.5)$ & Los Angeles & Policeman \\
related social & Clive & 70 & Male & 5 & San Francisco & Doctor \\
capital & Ellen & 62 & Female & 3 & Los Angeles & Curator \\
& Liz & 44 & Female & 1 & San Francisco & Unemployed \\
& Wendy & 48 & Female & 1 & San Francisco & Unemployed \\
& King & 70 & Male & 1 & Vancouver & Retired \\
& Grace & 60 & Female & 3 & Los Angeles & Professor \\
& Yannie & 51 & Female & 2 & Vancouver & Travel agent \\
& Joyce & 30 & Female & 2 & San Francisco & Museum \\
& Lee & 78 & Male & 1 & San Francisco & Retired \\
\hline No. of participants & 10 & & & & & \\
\hline Flourishing & Louise & 60 & Male & 1 & Los Angeles & Entrepreneur \\
networks across & Kathy & 60 & Female & 1 & San Francisco & Professor \\
communities & Andy & 57 & Male & 1 & Vancouver & Entrepreneur \\
& Tony & 40 & Male & 1 & Toronto & Entrepreneur \\
& Sabrina & 39 & Female & 1 & Los Angeles & Entrepreneur \\
& Harold & 40 & Male & 1 & Tokyo & Entrepreneur \\
& Will & 46 & Male & 1 & Manchester & Lawyer \\
\hline
\end{tabular}




\begin{tabular}{lllllll}
\hline & Huang & 52 & Male & 1 & Manchester & Entrepreneur \\
& Zack & 65 & Male & 1 & Vancouver & Public service \\
& Miu & 70 & Male & 1 & Vancouver & Retired \\
& Mable & 70 & Female & 1 & Vancouver & Retired \\
& Frankie & 53 & Male & 1 & Los Angeles & Self-employed \\
& Billy & 60 & Male & 1 & Vancouver & Judge \\
& Lam & 36 & Female & 1 & Toronto & Real estate \\
& & & & & & agent \\
\hline No. of participants & 14 & & & & & \\
\hline Temporary and & Seth & 42 & Male & 3 & Los Angeles & Museum \\
weak ties & Aaron & 51 & Male & 3 & Vancouver & Doctor \\
& Bob & 54 & Male & 3 & Vancouver & Travel agent \\
& Waldo & 50 & Male & 3 & Vancouver & Unemployed \\
& Martin & 43 & Male & 5 & San Francisco & Manager \\
& Mary & 60 & Female & 4 & Vancouver & Professor \\
& Kaley & 50 & Female & 4 & Vancouver & Professor \\
& Edward & 55 & Male & 2 & San Francisco & Entrepreneur \\
& Daisy & 60 & Female & 3 & Vancouver & Entrepreneur \\
\hline No. of participants & 9 & & & & & \\
\hline
\end{tabular}

